\title{
Mirosław S. WRÓBEL, Studia z Ewangelii Janowej, Tarnów 2010, 290 s. (W Kręgu Słowa, 5)
}

Po publikacji wielkich monografii Antyjudaizm a Ewangelia według św. Jana (Lublin 2005) oraz Synagoga a rodzacy się Kościót. Studium egzegetyczno-teologiczne Czwartej Ewangelii $(\mathrm{J} 9,22 ; 12,42 ; 16,2)$ (Kielce 2002), a zwłaszcza po wydaniu prestiżowej książki Who are the Father and his Children in Jn 8:44? A Literary, Historical and Theological Analysis of Jn 8:44 and its Context (Paris 2005), ks. dr hab. Mirosław S. Wróbel, profesor Katolickiego Uniwersytetu Lubelskiego Jana Pawła II, prowadzący od wielu lat pasjonujące badania egzegetyczne dzieła Janowego, oparte przede wszystkim na krytycznym podejściu do tekstów finalnych odczytywanych w świetle uwarunkowań socjo-religijnych, jak również w szerokim kontekście literatury międzytestamentalnej oraz kultury starożytnej, zaprezentował środowisku biblijnemu w Polsce nową publikację pt. Studia z Ewangelii Janowej (Tarnów 2010). Książka oprócz dwudziestu tematycznych artykułów (s. 19-221) obejmuje również bibliografię (s. 223-257) oraz dwa indeksy: autorów (s. 259-271) i odniesień do Ewangelii św. Jana (s. 273-290).

Badania nad Ewangelią według św. Jana w ostatnich latach przybrały nowy kierunek za sprawą rozwoju i zainteresowania w egzegezie biblijnej tzw. metodami synchronicznymi, a wśród nich metodą analizy narracji (na polu biblistyki polskiej trzeba przywołać nazwiska trzech uczonych, którzy mocno przyczynili się do propagowania badań metodą narratywną: H. Witczyk, W. Pikor oraz J. Kręcidło). Metoda narratywna traktuje tekst jako swoiste universum - świat zamknięty w sobie, poza który nie trzeba nigdzie wykraczać, by odkryć jego sens. By go poznać, nie potrzeba zajmować się środowiskiem, w którym dokument powstawał (Sitz im Leben), ani procesem jego przekazu od momentu zaistnienia faktu aż do redakcji finalnej (Redaktionsgeschichte), wystarczy jedynie dotrzeć do wszystkich sposobów ekspresji, za pomocą których autor pragnie komunikować się z odbiorcą. Metoda analizy narracji pozwala odczytać przesłanie najmniejszych elementów wyselekcjonowanej jednostki w ramach jej wewnętrznej spójności, natomiast w pewien sposób ogranicza dostęp do uwarunkowań historycz- 
nych wydarzenia, które bardzo często są „drugim narratorem” przekazującym odbiorcy pogłębiony sens zaistniałych i opisanych faktów.

W książce Studia z Ewangelii Janowej Mirosław S. Wróbel postarał się zharmonizować oba sposoby podejścia do tekstu natchnionego: zmierzyć się z zagadnieniami natury literackiej i historycznej (diachronia) bez „rozrywania” tekstu na niezliczone jednostki (co stanowi częsty zarzut dla metody historyczno-krytycznej), przy jednoczesnym potraktowaniu Ewangelii jako spójnej narracji (synchronia), za pomocą której autor natchniony pragnął skomunikować się z odbiorcą niezależnie od czasu i miejsca (warto zauważyć istotny element narracyjny, który zastosował autor: tytuły poszczególnych paragrafów są zapisane w formie pytań, jakie rodzą się w sercu i umyśle czytelnika Ewangelii Jana). Powyższy zamiar autor książki realizuje poprzez odpowiednie „nachylenie teologiczne" poszczególnych artykułów. Przy głębszej lekturze można bowiem zauważyć, że mają one podwójny charakter: artykuły I-XII posiadają „nachylenie” historyczno-krytyczne z ciągłym otwarciem na aspekty narratywne (czego najlepszym dowodem jest paragraf IX pt. Jaka jest funkcja „Żydów” w ujęciu narratywnym?), natomiast artykuły XIII-XX są wprowadzeniem w najgłębsze zagadnienia teologii św. Jana. Mirosław S. Wróbel prowadzi czytelnika do bardzo głębokich warstw przesłania „Czwartej Ewangelii”, do których dociera dzięki rzetelnie przeprowadzonej analizie egzegetycznej uwzględniającej z jednej strony fakt, że tekst Ewangelii Jana stanowi całościową jednostkę narracyjną (zastosowanie metody analizy narracji), przy równoczesnej świadomości bogactwa aspektów teologicznych, które przed badaczem odsłania analiza historyczno-krytyczna.

W pierwszej części książki (I-XII) do zasadniczych wątków tematycznych poruszonych przez autora należą najistotniejsze zagadnienia z zakresu krytyki tekstu (wartość tzw. „tekstu zachodniego” dla badań egzegetycznych), Sitz im Leben (pierwotny język Ewangelii Jana, kontekst socjoreligijny: wpływ Samarytan i środowiska związanego z Qumran na treść pisma, charakterystyka „Żydów”) oraz elementy historii redakcji istotne dla podejmowanych zagadnień. Lektura pierwszych paragrafów od razu nasuwa wniosek, że Mirosław S. Wróbel jest wybitnym znawcą dzieła Janowego. Świadczy o tym nie tylko trafność wyprowadzanych konkluzji, ale również swoboda języka, z jaką autor porusza się w skomplikowanych przestrzeniach literacko-historycznych, oraz niebywale bogaty i rzetelny aparat krytyczny dołączony do każdego z artykułów. Oczywiście praca ma charakter poszukiwawczy. Dzięki temu czytelnicy mogą z łatwością odnaleźć wątki, które domagają się dalszego pogłębienia i dyskusji. Jednym z nich jest - jak sądzę - często występujące wyrażenie „Jezus Janowy” (zob. s. 74, 75, 83, 194), które każdemu, kto choć trochę zna historię egzegezy biblijnej, nasuwa skojarzenie z poglądami R. Bultmanna czy G. Vermesa na temat historyczności Jezusa z Nazaretu oraz autentyczności przekazów ewangelicznych. Na szczęście autor książki nie nadużywa powyższego sformułowania i umieszcza je najczęściej w kontekście problemu tożsamości „Żydów”, z którymi w Janowej narracji Jezus wielokrotnie polemizuje. Z pewnością istotnym walorem badań egzegetycznych autora książki jest próba identyfikacji tej grupy adwersarzy Jezusa podjęta na bazie analizy wszystkich płaszczyzn historyczno-literackich: geograficznej, historycznej, socjologicznej, religijnej, symbolicznej i narratywnej (s. 59-64). 
Druga część książki (XIII-XX) stanowi wprowadzenie w najgłębsze pokłady teologii Janowej. Autor prezentuje w niej to, co wybitny znawca Ewangelii św. Jana, jakim jest R. Brown, określa mianem „teologii wyższej”, a więc zagadnienia z zakresu trynitologii. Ta część jest nie tylko zaproszeniem do intelektualnej wędrówki w głąb tajemnicy Trójcy Świętej, ale stanowi wezwanie do odpowiedzi na poznanie Boga (autor odwołuje się do terminów biblijnych jada i ginosko; zob. s. 163-164, 188) na płaszczyźnie wiary, która w Ewangelii Jana ma dynamiczny charakter i konkretyzuje się w egzystencjalnej odpowiedzi na usłyszane orędzie lub przeżyte doświadczenie (s. 181, 191, 214). Warto przy tym zauważyć, że występujące w książce powtórzenia (będące wynikiem odrębności każdego z artykułów) wpisują się w pewien sposób w styl Janowy, który wielu egzegetów określa mianem „spiralnego”. Jest on dobrze widoczny w Ewangelii oraz 1 Liście Jana i charakteryzuje się powtarzaniem tych samych wątków teologicznych w następujących po sobie częściach struktury.

Książka Mirosława S. Wróbla Studia z Ewangelii Janowej nie tylko znacząco dopełnia wcześniejszą pracę badawczą tegoż autora nad dziełem Janowym, ale dodatkowo mocno poszerza zakres studiów związanych z Ewangelią według św. Jana, które na gruncie biblistyki polskiej wyznaczają publikacje L. Stachowiaka, S. Gądeckiego, J. Kudasiewicza, H. Witczyka, S. Mędali, A. Paciorka oraz J. Kręcidły. Jej wysokich walorów naukowych nie obniża nawet niedostateczna precyzja edytorów serii (zwłaszcza błędy niezależne od autora, a wprowadzone przez edytora przy dzieleniu wyrazów greckich), jak również drobne uchybienia w translacji imion starożytnych pisarzy chrześcijańskich (zachowanie brzmień anglojęzycznych). W dobie ożywionego zainteresowania Pismem Świętym w wielu środowiskach chrześcijańskich dzieło Mirosława S. Wróbla stanowi bardzo dobrą pomoc do pogłębionego studium literacko-teologicznego Ewangelii według św. Jana. 